International Journal of Engineering \& Technology, $7(3.29)(2018) 121-124$
SPC
International Journal of Engineering \& Technology
Website: www.sciencepubco.com/index.php/IJET
Research paper

\title{
Rainfall-runoff modelling calibration on the watershed with minimum stream gage network data
}

\author{
Evi Anggraheni ${ }^{1}$ *, Dwita Sutjiningsih ${ }^{1}$, Jarot Widyoko ${ }^{1}$ \\ ${ }^{1}$ Civil Engineering Department, Faculty of Engineering, Universities Indonesia Depok, Indonesia Ciliwung-Cisadane River \\ Basin Agency, Jakarta, Indonesia \\ *Corresponding author E-mail: evi.anggraheni@eng.ui.ac.id
}

\begin{abstract}
The hydrological model has an important role to present the accurate and reliable information for water resources management. In this research, combination of HEC-GeoHMS and HEC-HMS that adopt the SCS-CN model have been chosen to analyse the hydrological characteristic at Upper Ciliwung Watershed. Ciliwung Watershed is one of 13 watersheds that has big influence to flood management in Jakarta. Flooding is the natural hazard that occurs every year at Jakarta. One of important part of flood early warning system at Jakarta is Katulampa Weir that located at Upper Ciliwung watershed. The area of it watershed is about $150 \mathrm{~km} 2$ that only has one stream gauge station at Katulampa. Accurate representation of rainfall runoff modelling at this location is important in order to predict the discharge and water infrastructure design. The objective of this paper is to obtain the parameter combination of Upper Ciliwung Watershed which can produce the discharge close to the discharge observation using HEC-HMS. The comparison between HEC-HMS and observation gage at Upper Ciliwung Watershed was calculated by Nash-Sutcliffe Efficiency (NSE) method. Nash value of discharge simulation at Upper Ciliwung Watershed compare with the discharge observation at Katumpa Weir reach up until 0,9.
\end{abstract}

Keywords: HEC-GEOHMS; Separated by Commas.

\section{Introduction}

Hydrological model plays an important role on the discharge forecasting to present the accurate and reliable information for water resources management [1] Hydrological modeling also could simulate the same measured rainfall with varying catchment condition to generate more data. The representation of watershed processes that influenced by complex spatio-temporal hydrological processes can be accommodated by the hydrological modeling [2]. The representation of watershed characteristic on the hydrological model is really important because the hydrological response is affected not only by rainfall but also the complex parameter of watershed [3]. Model calibration is a necessary requirement to obtain the flood prediction from the hydrological model. The availability of rainfal station and discharge gage data are the essential requirement to calibrate the hydrological model. Upper Ciliwung watershed is one of the most important section of Ciliwung watershed. The dendritic shape of Upper Ciliwung watershed may cause the flash flood at Katulampa Weir. Katulampa weir is one of several Jakarta early warning system location during rainy season. In order to predict the surface runoff, many hydrological model was applied at Upper Ciliwung Watershed. In 2016, Murniningsih,et.al.[4] identified the influence of spatial landuse variability at it watershed using WIN TR20 . The other study, assessment of climate and landuse change the impact of flooding at Upper Ciliwung watershed using HEC-HMS give the Nash value 0.6 to 0.8 [5]. Flooding is one of natural hazard that occur every year at Jakarta, the accurate predicting of flood is important to water management. Area of Upper Ciliwung Watershed is about $150 \mathrm{~km} 2$ only cover by three (3) rainfall station and one (1) automatic water level recording. In order to provide a better analyze of rainfall-runoff prediction at the outlet, development of approach system is necessary for hydrological models. HEC-GEO HMS (one interface of GIS) is a model that develop used the interface of GIS. This model used to help the user with limited GIS experience, an extension tool in ArcGIS called Hydrologic Engineering Center-GeoHydrologic Modeling System (HEC-GeoHMS) to provide geospatial hydrology modelling. The Objective of this research are to analyze the performance of HEC-GEO HMS in order to represent the watershed properties and to calibrate the performance of HEC-HMS at Upper Ciliwung Watershed using NashSutcliffe Efficiency (NSE) method.

\section{Research methodology}

a) Case Study Identification

Ciliwung is one out of 13 rivers, which flowing through Jakarta before debouching into the Java Sea, and the most influential river to Jakarta. The area of Ciliwung Watershed about $400 \mathrm{~km} 2$ with the longest river that flows across Bogor, Depok, South Jakarta and East Jakarta about $120 \mathrm{~km}$. Ciliwung watershed is one of critical watershed in Indonesia [6]. Upper Ciliwung watershed, from upstream until Katulampa weir, has a dendritic shape that characterizes the fast increasing flow or we called flash flood. Nevertheless, the downstream part of Ciliwung has elongated and narrowing shape. With this shape characteristic, the Upper Ciliwung Watershed has an important role, as contributor of runoff from the watershed, which is quite large. The boundary of Upper Ciliwung watershed is delineated from Gede Pangrango until Katulampa Weir at Bogor City. The watershed area is around $150 \mathrm{~km} 2$ and $25 \mathrm{~km}$ long. The Ciliwung Watershed and the discretization of Upper Ciliwung Watershed present at the figure 1 . 


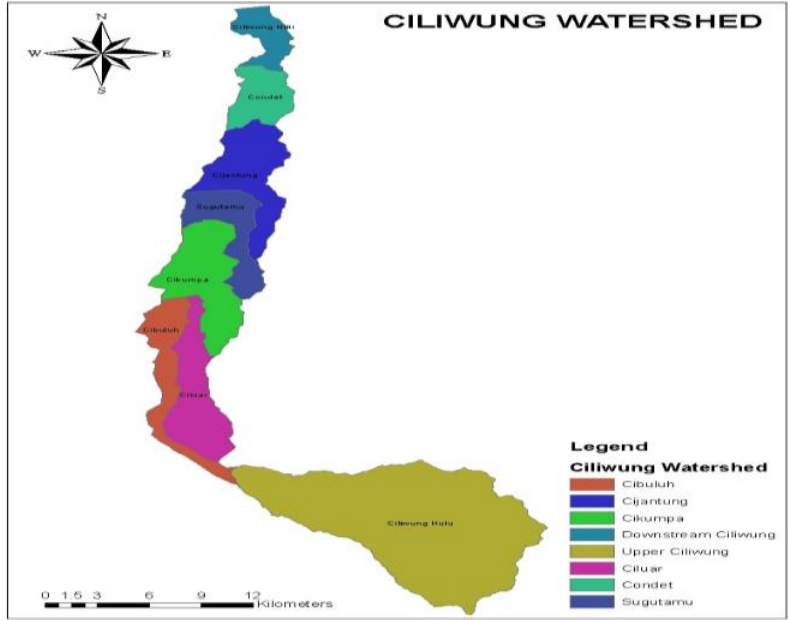

Fig. 1: Ciliwung Watershed and Upper Ciliwung Discretization.

b) Available Data Set

Daily rainfall data was collected from [3] (three) rainfall station, Gunung Mas, Cilember and Gadog for the past events (15 Feb 2017 7 March 2017, 13 April 2017 and 5 Feb 2018). Automatic Water Level Recorder (AWLR) as an observation data was obtained from Katulampa Weir station. All collected data supported by Ciliwung Cisadane River Basin Agency. Analysis of land cover at Upper Ciliwung Watershed was used landsat 8 digitation on 2017 over the catchment. CN grid map that represent the land cover at its catchment present at figure 2 .

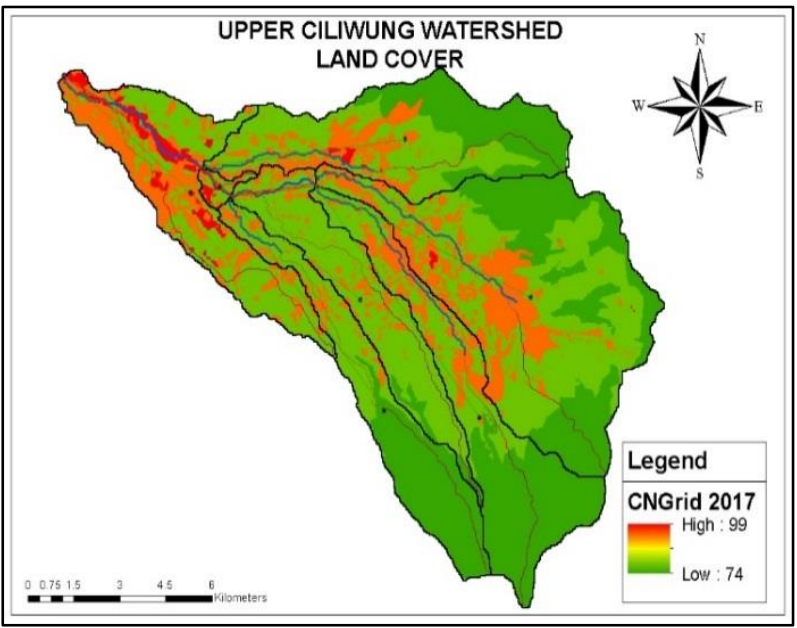

Fig. 2: CN Grid at Upper Ciliwung Watershed.

\section{c) HEC-GEOHMS}

"HEC-GeoHMS has been developed as a geospatial hydrology toolkit for engineers and hydrologists with limited GIS experience."[7]. This tool helps to analyze the digital terrain data, transforming to the drainage paths and watershed boundaries that represents the drainage network. The watershed delineation, and the spatial characteristic of its watershed ware proved by Geographical Information Systems (GIS). The spatial information of watershed characteristic and stream network in GIS is done by the interfaces of Arc-Hydro or HEC-Geo HMS. Schematic of Upper Ciliwung
Watershed based on HEC-GeoHMS interface can be seen at the figure 3.

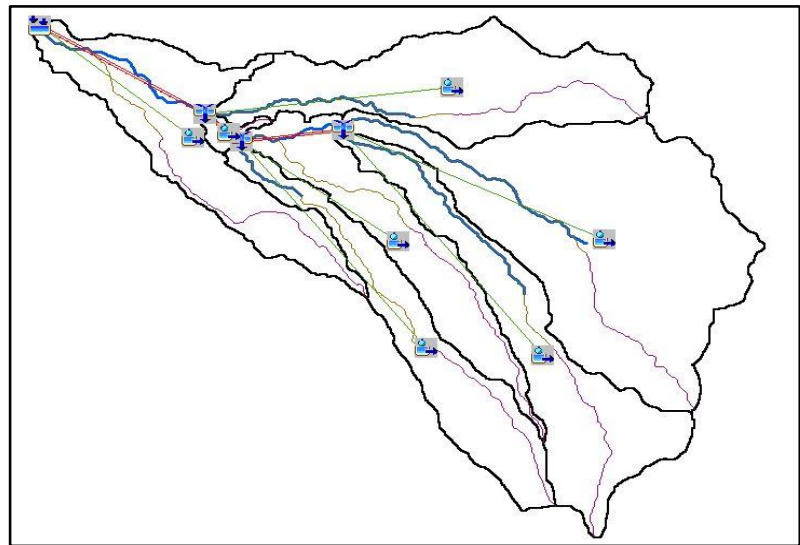

Fig. 3: Schematic of Upper Ciliwung Watershed Using HEC-Geohms.

d) Hydrological model HMS

The U.S. Army Corps of Engineers is the organization which develop the Hydrologic Engineering Center-Hydrologic Modeling System (HEC-HMS). This study used HEC-HMS version 4.0by interconnecting with HEC-GeoHMS. The purpose of this software is to simulate the hydrological process in a complete way of watershed system. The combination of meteorological data and watershed characteristic were combine in this model to simulate the hydrological response[8]. The meteorological parameter contains information about rainfall and snowfall. The control model contains information regarding the required simulation time period [7]. Several studies have been approved the performance of HEC-HMS either for gauge or ungauged watershed. HEC-HMS model adopted the Soil Conservation Service - Curve Number (SCS-CN) method for the production function. The representation of hydrological process at the watershed consider by it production function depends on the $\mathrm{CN}$ value, the soil characteristic and the 5 day-antecedent rainfall. The formulation of SCS-CN method presents at the equation 1-5[9]:

$\frac{F_{a}}{S}=\frac{P_{a}}{P-I_{a}}$

From the continuity principle

$\mathrm{P}=\mathrm{P}_{\mathrm{e}}+\mathrm{I}_{\mathrm{a}}+\mathrm{F}_{\mathrm{a}}$

$\mathrm{P}_{\mathrm{e}}=\frac{\left(\mathrm{P}-\mathrm{I}_{\mathrm{a}}\right)^{2}}{\mathrm{P}-\mathrm{I}_{\mathrm{a}}+\mathrm{S}}$ Where as $\mathrm{I}_{\mathrm{a}}=0.2 \mathrm{~S}$

$\mathrm{P}_{\mathrm{e}}=\frac{(\mathrm{P}-0.2 \mathrm{~S})^{2}}{\mathrm{P}+0.8 \mathrm{~S}}$

Where $P$ is the total rainfall, $I_{a}$ is the initial abstraction, $Q$ is direct runoff and $S$ is the retention capacity of catchment area. Value of $S$ depend on the value of Curve Number $(\mathrm{CN})$ which is around 0 to 100 .

$$
\mathrm{S}=25.4\left(\frac{1000}{\mathrm{CN}}-10\right)
$$

Table 1: Watershed Parameter

\begin{tabular}{|c|c|c|c|c|c|c|c|c|c|c|c|}
\hline $\begin{array}{l}\text { grid } \\
\text { code }\end{array}$ & $\begin{array}{l}\text { Shape } \\
\text { Length (m) }\end{array}$ & Name & $\begin{array}{l}\text { Slope } \\
(\%)\end{array}$ & $\begin{array}{l}\mathrm{CN} \\
\text { III }\end{array}$ & $\begin{array}{l}\mathrm{CN} \\
\mathrm{III}\end{array}$ & $\begin{array}{l}\text { Area } \\
\left(\mathrm{km}^{2}\right)\end{array}$ & $\begin{array}{l}\text { S CN II } \\
(\mathrm{mm})\end{array}$ & $\begin{array}{l}\text { S CN III } \\
(\mathrm{mm})\end{array}$ & $\begin{array}{l}\text { Ia CN II } \\
(\mathrm{mm})\end{array}$ & $\begin{array}{l}\text { Ia CN III } \\
(\mathrm{mm})\end{array}$ & $\begin{array}{l}\text { Percent Imper- } \\
\text { vious }(\%)\end{array}$ \\
\hline 1 & 42780 & W80 & 9.74 & 74 & 85.7 & 20.81 & 3.57 & 1.67 & 0.71 & 0.33 & 61.9 \\
\hline 2 & 38220 & W90 & 26.90 & 64 & 79.5 & 25.67 & 5.72 & 2.58 & 1.14 & 0.52 & 47.1 \\
\hline 3 & 7920 & W100 & 13.20 & 74 & 85.8 & 1.10 & 3.50 & 1.66 & 0.70 & 0.33 & 47.1 \\
\hline 4 & 45780 & W110 & 27.27 & 64 & 79.8 & 48.86 & 5.63 & 2.53 & 1.13 & 0.51 & 40 \\
\hline 5 & 38520 & W120 & 19.24 & 64 & 79.6 & 16.28 & 5.72 & 2.56 & 1.14 & 0.51 & 37 \\
\hline 6 & 45540 & W130 & 35.58 & 62 & 78.3 & 23.16 & 6.21 & 2.77 & 1.24 & 0.55 & 57 \\
\hline 7 & 41160 & W140 & 39.64 & 60 & 76.9 & 16.97 & 8.87 & 3.00 & 1.77 & 0.60 & 5 \\
\hline
\end{tabular}


e) E. Model Simulation and Calibration

Upper Ciliwung watershed was used to calibrate the model. Daily rainfall data for 4 (four) events and land cover in 2017 over the watershed was inserted to the model. First simulation was done by the $\mathrm{CN}$ value type II that usually used based on the $\mathrm{CN}$ table. Second simulation was considered the 5 days antecedent rainfall condition before the event. Last simulation (Simulation III) was calculated by take into account the 5 days antecedent rainfall, soil abstraction and percent impervious over each sub watershed.

The Nash-Sutcliffe Efficiency (NSE) method was used to define the comparison between relative values of residual variance with the measured data variance [10]

$$
E=1-\frac{\sum_{i=1}^{n}\left(O_{i}-P_{i}\right)^{2}}{\sum_{i=1}^{n}\left(O_{i}-\bar{O}\right)^{2}}
$$

It gives indication of how well the observed data versus simulated data fits the linear regression (1:1). The value ranges from- $\infty$ to 1.0 . The closer value is to [1], means that the simulation close to the observation value.

\section{Result and discussion}

The objective of this step is to verify the coherence of the hydrological model HEC-HMS. For this step, a comparison of the modeled hydrographs and the measured hydrographs at the outlet (Katulampa Weir) of [7] sub-watersheds has been done for [4] events and 3 Simulation. Using HEC-HMS, we can simulate the rainfallrunoff processes in watershed for varied purposes such as water supply scheme, flood forecasting and so on. To develop a hydrological model, we use a project name to identify the project. A project has three models, basin, meteorological, and run control.

More than $30 \%$ land cover at Upper Ciliwung watershed is a buildup area (See Figure 2). For computation using HEC-HMS, the Upper Ciliwung watershed is divided into 7 sub-watersheds (Figure 3) by HEC-GeoHMS tools. The distribution of sub-watershed parameter, HEC-HMS input data, can be seen at the table 1.

The meteorological model obtained of [3] rainfall stations represent by Thiessen Polygon for area rainfall. This proses represent the semi distributed method of hydrological modeling.

The result of HEC-HMS model for [4] events present at the figure $4 \mathrm{a}$ to $4 \mathrm{~d}$ bellow.

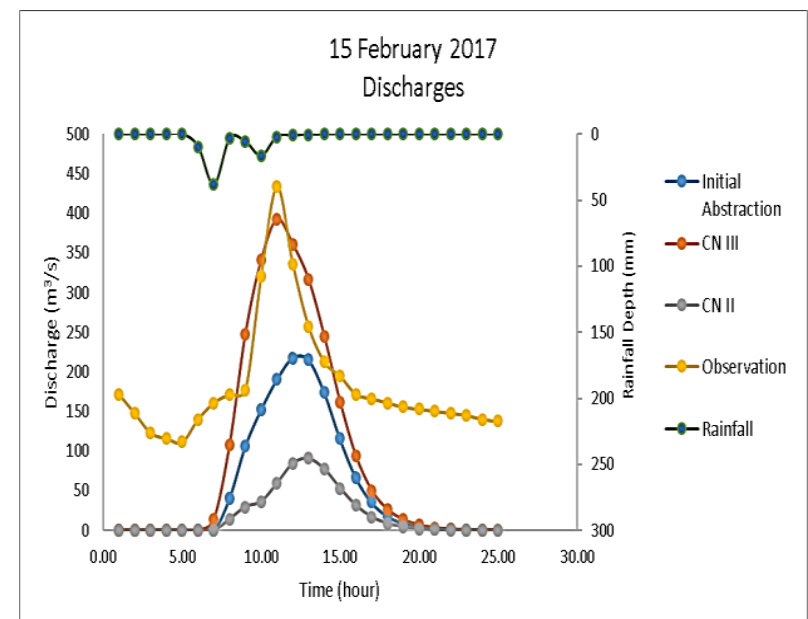

Fig. 4: A) Simulation and Observation Hydrographs at 15 February 2017.

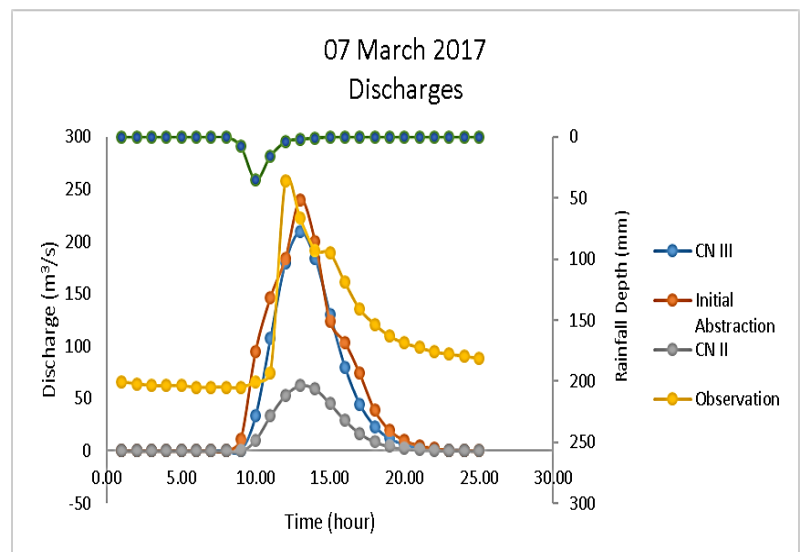

Fig. 4: B) Simulation and Observation Hydrographs at 7 March 2017.

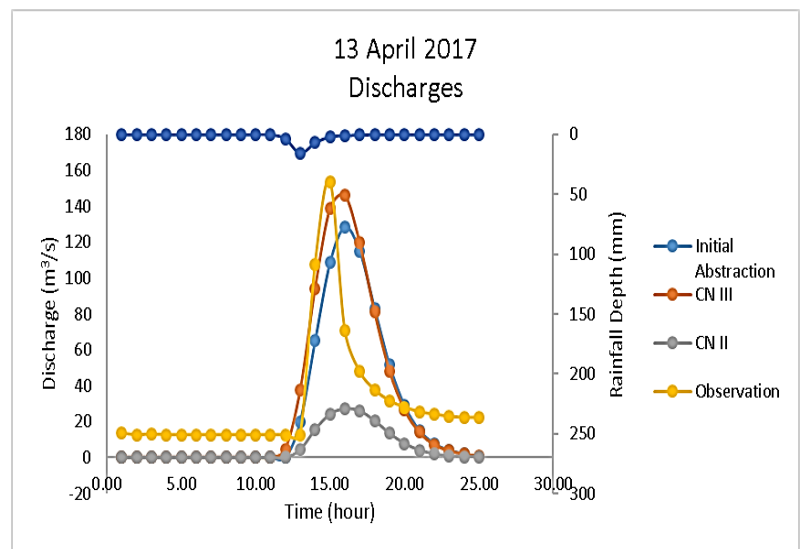

Fig. 4: C) Simulation and Observation Hydrographs at 13 April 2017.

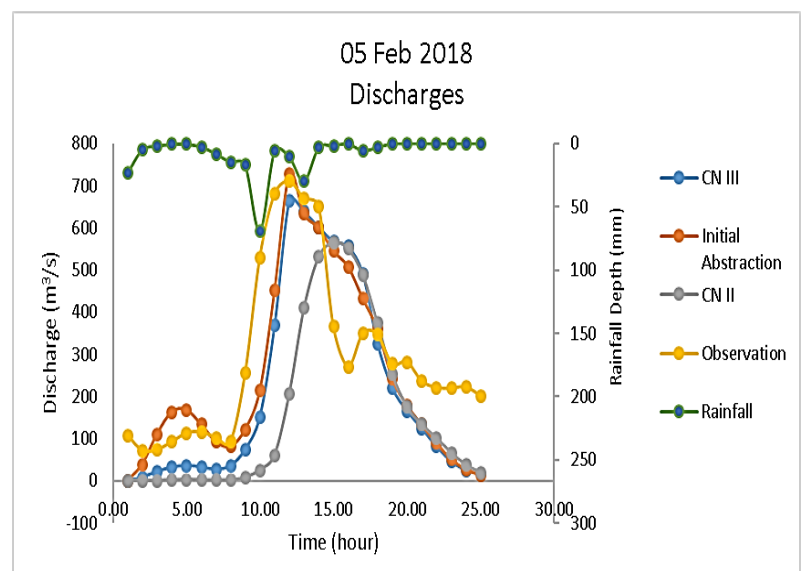

Fig. 4: D) Simulation and Observation Hydrographs at 5 February 2018

Table 2: Simulation Result Summary

\begin{tabular}{|c|c|c|c|c|c|c|c|}
\hline \multirow[t]{2}{*}{ Events } & \multicolumn{3}{|c|}{$\begin{array}{l}\text { Simulation (Peak Discharge } \\
\left.\left(\mathrm{m}^{3} / \mathrm{s}\right)\right)\end{array}$} & \multirow{2}{*}{$\begin{array}{l}\text { Obs } \\
\mathrm{m}^{3} /\end{array}$} & \multicolumn{3}{|c|}{ Nash Coefficient } \\
\hline & I & II & III & & I & II & III \\
\hline $\begin{array}{l}\text { 15-Feb- } \\
17\end{array}$ & 90.8 & 217.7 & 392.7 & $\begin{array}{l}433 . \\
7\end{array}$ & $\begin{array}{l}0.37 \\
5\end{array}$ & $\begin{array}{l}0.75 \\
2\end{array}$ & $\begin{array}{l}0.99 \\
1\end{array}$ \\
\hline $\begin{array}{l}\text { 7-Mar- } \\
17\end{array}$ & 62.5 & 209.6 & 239.2 & $\begin{array}{l}257 . \\
7\end{array}$ & $\begin{array}{l}0.42 \\
6\end{array}$ & $\begin{array}{l}0.96 \\
5\end{array}$ & $\begin{array}{l}0.99 \\
5\end{array}$ \\
\hline $\begin{array}{l}\text { 13-Apr- } \\
17\end{array}$ & 27 & 128.4 & 146.2 & $\begin{array}{l}153 . \\
6\end{array}$ & $\begin{array}{l}0.32 \\
1\end{array}$ & $\begin{array}{l}0.97 \\
3\end{array}$ & $\begin{array}{l}0.99 \\
8\end{array}$ \\
\hline $\begin{array}{l}\text { 5-Feb- } \\
18\end{array}$ & 566 & 664.1 & 727.5 & $\begin{array}{l}710 . \\
2\end{array}$ & $\begin{array}{l}0.95 \\
9\end{array}$ & $\begin{array}{l}0.99 \\
6\end{array}$ & $\begin{array}{l}0.99 \\
9\end{array}$ \\
\hline
\end{tabular}

The summary result of the three (3) simulations are presented table 2 above. The result shown the magnitude peak discharge between 3 
simulations. Furthermore, the simulation III obtain the nearby magnitude of peak discharge and the Nash value close to 1 for all events. Its mean that the more optimal result is produced by the model.

\section{Conclusions}

This paper presented the watershed properties at Upper Ciliwung Watershed using HEC-GeoHMS tools in Arc.GIS. The results indicate the good performance of HEC-GeoHMS at Upper Ciliwung watershed for watershed parameter identification. HEC-HMS shown a good performance also for the third simulation that take into account to the rainfall, land cover, soil moisture, and initial abstraction. For that simulation, Nash value are close to 1 . The watershed parameter interaction between the rainfall and other spatial watershed characteristic distribution, like soil properties, land cover and initial abstraction will make a better analysis of the watershed response [11].

\section{Acknowledgement}

We would like to address our gratitude to Universitas Indonesia for giving financial support through the PITTA 2018 funding scheme number 2423 /UN2.R3.1/ HKP.05.00/2018. Also thanks to Ministry of Public Work for all supporting data.

\section{References}

[1] Djodjic, F., Montas, H., Shirmohammadi, A., Bergström, L., \& Ulén B. (2001). A Decision Support System for Phosphorus Management at a Watershed Scale. Journal of Environmental Quality Vol. 31 No. 3, 937-945.

[2] Öztürk, M., Copty, N. K., \& Saysel, A. K. (2013). Modeling the Impact of Land Use Change on the Hydrology of a Rural Watershed. Journal of Hydrology, 97-109.

[3] An Anggraheni, E., Sutjiningsih, D., Emmanuel, I., Payrastre, O., \& Andrieu, H. (2018). Assessing the role of spatial rainfall variability on watershed response based on weather radar data (A Case study of the Gard Region, France). International Journal of Technology, $37-$ 46.

[4] Murniningsih, S., \& Anggraheni, E. (2016). Identification the Effect of Spatial Land Use Variability Using Gis at the Upstream Ciliwung Watershed. ARPN Journal of Engineering and Applied Sciences, 11.

[5] Emam, A. R., Mishra, B. K., Kumar, P., Masago, Y., \& Fukushi, K (2016). Impact Assessment of Climate and Land-Use Changes on Flooding Behavior in the Upper Ciliwung River, Jakarta, Indonesia. Water, 8(12).

[6] Yudha, B. W. (2015). Prediksi Laju Erosi Potensial dan Laju Timbulan Sampah Potensial pada Luasan Penutup Lahan Kedap Air (Studi Kasus DAS Ciliwung) Berbasis Sistem Informasi Geografis (SIG). Depok: Universitas Indonesia.

[7] Fleming, M. J., \& Doan, J. H. (2009). HEC-GeoHMS Geospatial Hydrologic Modeling Extension. Davis, CA: US Army Corps of Engeneering Hydrologic Engineering Center.

[8] OLEYIBLO, J. O., \& LI, Z.-j. (2010). Application of HEC-HMS for flood forecasting in Misai and Wan'an catchments in China. Water Science and Engineering, 3(1), 14-22.

[9] USDA SCS, U. S. (1985). National Engineering Handbook (Vol. Section 4). Washington, D.C.: Hydrology USDA-SCS.

[10] Nash, J., \& Sutcliffe, J. (1970). River Flow Forecasting through Conceptual Models Part I-A Discussion of Principles. 10.

[11] Douinot, A., Roux, H., Garambois, P.-A., Larnier, K., Labat, D., \& Dartus, D. (2016). Accounting for Rainfall Systematic Spatial Variability in Flash Flood Forecasting. Journal of Hydrology, 541 